\title{
The Personality of a Good Language Learner: A Case Study in an EFL Context
}

\author{
Puji Astuti Amalia, ${ }^{1 *}$ Aridah ${ }^{2}$ \\ ${ }^{1}$ Politeknik Negeri Samarinda, Samarinda, Indonesia \\ ${ }^{2}$ Universitas Mulawarman, Samarinda, Indonesia
}

\begin{abstract}
This case study aims to explore how the personality traits of a good language learner contributed to her success in language learning. Using a case study design, this study involved one student who met the criteria of a good language learner who became a champion of English competitions. This study used the Myers-Briggs Type Indicator personality test and semi-structured interviews to collect the data. The study showed that Meta's extrovert personality was described as talkative, confident, enthusiastic, and assertive. She understood a problem by talking about it and heard others' ideas in solving problems. As a sensing personality, she was objective and made decisions based on logic and facts to decide both sides. As a thinking person, she always worked with plans, and in making plans, she analyzed the pros and cons. She was objective and consistent in doing what she had planned. Her judging personality described how she dealt with their outer world. She had a decided lifestyle that had helped her achieve her goals in language learning by planning her language learning activities.
\end{abstract}

Article Information

Received 10 August 2021

Accepted 21 Sepetember 2021

Published November 6, 2021

Keywords: Good language learner; English Language Learning; personality

\section{Introduction}

Good language learners can be defined as successful users of language learning strategies. Good language learners have certain strategies in their language learning which help them succeed (Takeuchi, 2003). However, the use of language learning strategies is not the only factor, which can help students become good language learners. Good language learners do not use the same language strategies. Even if

*Corresponding Author: Puji Astuti Amalia (pujiastutiamalia@polnes.ac.id) Jl. Cipto Mangun Kusumo, Sungai Keledang, Kecamatan Samarinda Seberang, Samarinda, East Kalimantan, Indonesia 75242 they use the same strategies, they may not use them for the same purposes in the same way. An individual and contextual condition that influences one's learning leads to the learner's belief, motivation, and learning strategy (Palfreyman, 2002). In line with this, a study conducted by Jafari et al. (2020) revealed that language learners' individuality constructs certain language learning strategies resulting in successful language learning. This indicates that there are certain variables that may affect language learning or even help a student become a good language learner; one of them is personality (Griffiths, 2008).

Personality, as one variable which is hypothesized to affect language learning 
success, is defined as a set of characteristics possessed by an individual. These characteristics influence one's cognition and motivation (Mammadov, 2016). Personality also refers to individual differences in patterns of thinking, feeling, and behaving (Alan E. Kazdin, 2000). In addition, personality is the combination of the characteristics possessed by a person which influence the person's attitudes, beliefs, thought, actions, feelings, motivations, and behaviors in various situations. It differs oneself from others and becomes a typical of oneself. It is also recognized by others.

Personality is classified into some types. Personality types refer to the psychological classifications of different people. In this study, the classifications of personality are adopted from different experts. The first classification comes from (Myers et al., 1998). Myers et al. divided personality into four dichotomous scales. They are Extraversion-Introversion, Sensing-Intuition, Thinking-Feeling, and Judging-Perceiving. The second classification is more specific, which is called MBTI (MyersBriggs Type Indicator). In MBTI, Myers and Briggs combine the dominant personalities into 16 types; one of the 16 types is ISTJ which means Introversion, Sensing, Thinking, and Judging.

Research in education has shown that personality is able to help learners shape their learning strategies. A study by Kamarulzaman (2012), for example, found that personality has an effect on the way students learn. An extrovert learner who has such characteristics as talkative, active, and fun-loving learn by using concrete experience and active experimentation. This finding shows that there are certain factors that shape learners' learning strategies to make them successful in language learning, including the characteristics of the learners such as learning style preferences, motivation to learn the language, and personality. The result of pre-observation in this study indicated that there was a student in one class who had a highly distinctive performance in language learning. Compared to other students in the classroom, she was superior in almost all aspects of language learning, including all of the language skills and components. She was always successful in completing all of the tasks given to her without having any difficulties related to language use. In short, she can be regarded as a good language learner. Further observation revealed that her success in language learning was related to her personality. It was found that her personality helps her be a good language learner. The study showed that the individual tried to be an ideal learner, and this situation motivated her to make an effort in her language learning; this led her to achieve a high level of linguistic competence (Dörnyei \& Ushioda, 2009). The language learner in this study graduated with an average GPA of 3.84. She also won various English competitions; one of them was National University English Debating Championship. From the observation, it was found that she possessed a unique personality that helped her shape her motivation and learning strategies. Therefore, this study aims to deeply examine her personality that was believed to contribute to her success in learning English.

\section{Method}

This qualitative research employed a case study design. The case study describes the 
subject and offers conclusions (Robert $\mathrm{K}$ Yin, 2000). In this study, the subject was an individual investigated in-depth in order to find her characteristics as a good language learner in relation to her personality. The subject in this study is an English Department student named Meta (pseudonym). This study ensured anonymity and privacy (confidentiality) as part of ethical principles in qualitative research (Orb et al., 2001).

To collect the data, the researchers used two instruments. The first instrument was a questionnaire. The questionnaire was distributed in order to collect data about the characteristics (Marshall \& Rossman, 1990). Therefore, the questionnaire was given to find out her personality then she was given a set of questions to get more information about her personality that contributed to her language learning. The questionnaire was used to identify the personality of the subject as MBTI (MyersBriggs Type Indicator) (Myers et al., 1998). MBTI questionnaire is considered a reliable personality test (Pittenger, 2005). MBTI is an instrument; it is a forced-choice that measures four dimensions of an individual's personality such as Extroversion-Introversion, SensingIntuitive, Thinking-Feeling, and JudgingPerceiving. Kirby and Barger (1998) reviewed various studies to provide significant evidence for the reliability and validity of MBTI in a variety of groups which have different cultures.

The MBTI questionnaire was analyzed by finding the highest point in the four pairs of dichotomous scales. It was done by summing the score in each category of eight categories; they were Extroversion-Introversion, SensingIntuitive, Thinking-Feeling, and JudgingPerceiving. It could be concluded that the highest point among the eight categories of Extroversion-Introversion, Sensing-Intuitive, Thinking-Feeling, and Judging-Perceiving were the most dominant personality had by the subject.

The second instrument was an open-ended interview (Creswell, 2014). This study used semi-structured in-depth interviews. The questions on the interview guideline focused on the specific personality of the subject in the study. The data obtained from the semistructured Individual in-depth interview were analyzed using Flow Diagram, which included three concurrent activities: data reduction, data display, and conclusion drawing (Huberman \& Miles, 2002).

In addition, there were two kinds of triangulation used in this study to increase the validity of the finding. The first was data triangulation. Data triangulation is the process of gathering the slices of data (Denzin, 2006). In data triangulation, data were retrieved from several sources such as questionnaires, semistructured in-depth interviews, and documents (the copy of Kartu Hasil Studi or Grade Point Average Result), some certificates, and memos of the subject). This study also interviewed the subject's closest friend, who knew the subject's personality very well. She was interviewed in order to obtain valid information about the subject's personality.

The second triangulation was theory triangulation. Theory triangulation involves the use of multiple professional perspectives in order to interpret a single set of data/information (Lisa A. Guion, David C. Diehl, 2011). The data relating to the characteristics of a good language learner in this study were compared to the theories of (Zare, 2012). 
Meanwhile, the findings related to personality was compared by the theories of (Myers et al., 1998).

\section{Findings and Discussion}

The result of the MBTI questionnaire (Myers et al., 1998), which was translated and formed in excel by Murdika (2011), showed that Meta has certain dominant personalities. They are ESTJ (combination of Extroversion, Sensing, Thinking, and Judging), as presented in Table 3

\section{Table 1}

\begin{tabular}{llll}
\hline Introvert: & $47 \%$ & Extrovert: & $53 \%$ \\
Sensing: & $80 \%$ & Intuition: & $20 \%$ \\
Thinking: & $73 \%$ & Feeling: & $27 \%$ \\
Judging: & $93 \%$ & Perceiving: & $7 \%$ \\
\hline
\end{tabular}

The Result of

Subject's

Personality.
The data in Table 1 indicated that the subject possessed such personality as Extroversion, Sensing, Thinking, and Judging
(ESTJ). . The characteristics related to her personality are displayed in the following table and will be explained one by one afterward:

\section{Table 2}

Summary of the subject's characteristics related to her personality

\begin{tabular}{|c|c|}
\hline Extrovert & Thinking \\
\hline $\begin{array}{l}\text { 1. She was talkative } \\
\text { 2. She was confident } \\
\text { 3. She was enthusiastic } \\
\text { 4. She was assertive } \\
\text { 5. She got energy from active } \\
\text { involvement }\end{array}$ & $\begin{array}{l}\text { 1. She analyzed the pro and cons in } \\
\text { making decisions } \\
\text { 2. She was objective, making } \\
\text { decisions based on logic and facts } \\
\text { 3. She was consistent and decisive in } \\
\text { making and applying decisions }\end{array}$ \\
\hline Sensing & Judging \\
\hline $\begin{array}{l}\text { 1. She remembered and paid } \\
\text { attention to the detail of } \\
\text { information. } \\
\text { 2. She learned best by doing or } \\
\text { experimenting }\end{array}$ & $\begin{array}{l}\text { 1. She had a structured life, taking } \\
\text { control of her life by making many } \\
\text { plans } \\
\text { 2. She was good at meeting deadline } \\
\text { 3. She had difficulty in adapting to } \\
\text { unpredictable situations }\end{array}$ \\
\hline
\end{tabular}


4. She paid attention to the products.

\section{Extroversion}

Extroversion was the first personality feature possessed by Meta. Extraversion is the term used to explain different attitudes people use to direct their energy. The essential characteristics of extrovert people are talkative, and they get energy from active involvement. This was in line with what this research found that Meta possessed some characteristics as an extrovert such as talkative, confident, enthusiastic, and assertive. She also obtained energy from active involvement. These characteristics are explained as follows:

\section{Talkativeness}

In the classroom, Meta was an active student who liked to speak, such as answering lecturers' questions, giving comments, and asking questions. Ade, one of Meta's closest friends who graduated from the same school and sat in the same class in the English department for almost four years, mentioned that Meta was a talkative student in the class, as she said "...She raised a hand and tried to answer a question even though she was not sure with her answer" (143)

Meta realized that in order to be fluent in English, she needed to have many opportunities to use English by practicing. She knew that learning from the classroom and books were not enough. Therefore, she joined communities or organizations where she had much time to practice her English, as stated by Meta, "...in Junior High School. English
Community, in Senior High School.English club. In University. English community..(14)"

Meta was a typical person who understood a problem by talking about it. She preferred to talk and hear others in understanding and solving problems. The condition made Meta like sharing and listening to others' ideas when she worked both inside and outside the classroom. Her classmate, Ade, stated, "She talks very often, she gives her ideas, and she listens to others' ideas too..." (32).

In light of the findings above, it is proved that as an extrovert person, Meta talked actively; she likes to share her ideas and listen to others' ideas. She likes speaking not only in the classroom but also outside of the classroom.

\section{Confidence}

The next personality characteristic possessed by a good language learner is confidence. It was found that Meta had a very good speaking ability and her confidence was one of the factors which helped her be a good English speaker. . Meta was very confident. Her self-confidence helped her talk actively in front of people, as stated by Meta, "I like to talk in the classroom, giving opinion to others, and I don't look like a shy person" (151). Ade also added, "She is very confident in speaking." (137).

The fact that Meta had a high selfconfidence and that this confidence helped her be a good speaker, particularly when she was speaking in front of people, show that in order 
to be a good language learner, an individual should have high self-confidence.

\section{Enthusiasm}

Another characteristic that influenced her speaking ability and achievement in language learning and teamwork was her enthusiasm. It was found that she had a big enthusiasm related to English, such as enthusiasm in learning English in the classroom, enthusiasm in working in a team or group work related to English assignments, and enthusiasm in using her English skills in certain activities outside of the classroom.

In the classroom, she showed her enthusiasm in learning English by sharing her ideas, asking and answering questions from the lecturer, using the language well in the class; as stated by Meta, "I like talking in the classroom, giving opinion to others," (151). It was also supported by Ade, "...She raised a hand and tried to answer" (143). Furthermore, Ade stated that when there was an English project, Meta was the most excited member of the group. Ade stated, "She is very enthusiastic, and sometimes she is dominant her group." (28)

Besides enthusiasm in learning English and working in a group, she also has enthusiasm in practicing her English skills. It is proven by some activities that she joined outside of the classroom related to English. Meta had a huge enthusiasm for joining the English debate, as stated by Meta, "Now, I focus on being a debater. Debate is the way to become a better language learner... (255). It was also supported by Wilma, "debate is $M^{* * * \prime s}$ passion. Meta likes public speaking." (62).

Joining the English club was not the only activity that aroused her enthusiasm. She was also very enthusiastic about participating in English competitions. Wilma stated that Meta often joined English competitions. She said: "In senior high school, she joined English debate competitions in junior high school she often joined English speech competitions." (133)

All of the data presented above show that Meta was very enthusiastic about learning and using English. She had enthusiasm in language learning inside the classroom, enthusiasm in group work, enthusiasm in participating in activities outside of the classroom related to English in which she could perform and improve her English skills.

\section{Assertion}

An assertion is the next characteristic possessed by Meta. As an assertive person, she was strict, especially in running plans or rules. She was assertive in implementing her plans and less considered others' personal feelings, as stated by Ade, "...She said, "you can be sad, but after you finish your job." (83). Her assertive characteristic could also be seen from the interview session. She talked assertively. It seemed like there was a space in every word, and she also emphasized certain words, which were the points of her ideas. All of this evidence showed that Meta was an assertive individual who had made her a good language learner.

\section{Active involvement}

The last characteristic that Meta had related to Extroversion is Active Involvement. It was found that Meta obtained energy from active involvement in organizations. This energy made her excited about being around people. She, therefore, is involved in some organizations such as theater and English clubs. Since she had a thinking personality, all the decisions that she 
made were based on logical consequences. One of the decisions that she made was joining an organization or community which could help her improve her English.

As an individual who is actively involved in the community, she believed that practicing English in an English club or English organization could improve her English. Meta said: "...I focus on English Community rather than the theatre" (22). Meta also mentioned other English clubs that she joined, "...in Junior High School I have joined English Community, in Senior High School I also joined English club, in University I joined English community...it focuses on English debate" (14). She was really attracted by English debates; therefore, she always joined the debate in MDS (Mulawarman Debating Society) and became a member of this organization. She stated, "From debate training, I train my English with other debaters." (257). All of the information given by Meta indicated that she got energy from her active involvement in the community. Through her involvement, she worked with other language learners in improving her English skills.

The case of Meta described above showed that an extrovert person. This is characterized by some qualities such as enjoying socialization, getting energy from active involvement, having an enthusiasm, being talkactive, and taking initiative in work (Woosley, 2001). All of these qualities were also possessed by Meta. Her quality as a talkative person made her confident in speaking. Moreover, since she liked taking the initiative in work, she seemed to be assertive. As an extrovert, Meta also had many opportunities to practice her English in order for her to become a good language learner.
The finding of the study supports the idea that personality may be a major factor in the acquisition of conversational skills, and an extrovert person is well suited to language learning (Lightbown, 2013). This is also parallel to the idea that one of the qualities that characterize a good language learner is that a good language learner creates opportunities for practice in using the language inside and outside the classroom (Zare, 2012). Based on the responses of the subject in this study, supported by the theories above, it can be concluded that Meta was a good language learner who made use of her quality to practice her English a lot not only in the classroom but also outside the classroom.

\section{Sensing}

The second type of personality possessed by Meta was sensing. Sensing personality refers to the way people take in information. The essential characteristics of sensing are paying attention to the detail and remembering the detail, seeing the practical use of things, and learning best when they see how to use what they are learning. In other words, in sensing, people learn by doing. It was found that Meta possessed two characteristics as a sensing person. She paid attention to the detail and remembered details. She also gave more attention to experience than to words. In other words, she learns by doing. The following are the qualities that Meta possessed as a sensing person:

\section{She remembered details and paid attention to the details of the information.}

Categorized as a good learner, Meta was found to pay attention to details, and she also remembered things by the details. This kind of 
personality helped Meta in retaining information she obtained from the learning process. She used details as her strategy in remembering, as stated by Meta, “...Remember things by picture are easier... (143). Ade, her classmate, also stated that "... She is very detailed." (65). This finding indicated that to be a good language learner, Meta paid attention to the details.

\section{She learned best by doing or experimenting}

The result of the questionnaire showed that Meta had a sensing personality. As a sensing person, she learned best by doing or experimenting. Meta understood that learning from books by reading and memorizing was not enough. She needed to experiment with her language learning by practicing, as Meta stated, "...I want to...practice more in English club..." (22). Therefore, she chose to join an English club, especially the debate club, as one of her ways to practice and to experiment in using English because she believed that in English debate, she could use her knowledge and experiment them, as stated by Meta, "in debate, we train every skill such as speaking, listening, reading and writing. I learn so much from debate. (255).

It was also reported that Meta experimented with language learning not only by speaking but also through writing. Since Meta was sensing, she noticed facts, paid attention, and remembered details in receiving information. Ade stated that Meta had her best way of understanding or remembering information. When Meta got information by written texts or spoken forms, she experimented with it in writing by making a summary. It helped her remember the information, as Ade stated, "... she made a summary in order to remember material which was taught by Mr. Sarangan.. (150)"

Besides practicing in speaking and writing, Meta also had creative techniques in experimenting with her language, especially English words, that is, by making a connection between the word and the picture in her mind. Meta stated, "I prefer reading and visualization because these techniques are really suitable for me." (185). This statement was also supported by Wilma "It is like a mind map. Sometimes she associates English word and picture." (6)

The data above indicated that Meta's personality, sensing, had contributed to her success in language learning. All of the characteristics related to sensing were possessed by Meta. Sensing people are concrete thinkers recognizing details. They pay attention to the detail and learn best by experimenting (Mudrika, 2011). Learning by doing is also one characteristic of a good language learner. One characteristic of a good language learner is trying to feel the language by experimenting with its grammar and words (Zare, 2012).

The explanation and the theories show that Sensing personality is helpful in retrieving information because people possessing this personality pay attention to the details and experiences and will try to experiment with the information that they get in language learning in order for them to become good language learners. All of the data of this data presented above had proved that Meta was a good language learner with a sensing personality that helped her in remembering and understanding information related to language learning by 
paying attention to details and attempting to experiment with it.

\section{Thinking}

Thinking, as one of the qualities possessed by a good language learner, refers to the way people make a decision. It was found that Meta had a thinking personality. In making a decision, Meta analyzed the pro and cons. She was objective, and she made decisions based on logical reasons. She was also consistent and decisive in making and applying decisions. All of these characteristics are explained as follows:

\section{She analyzed the pros and cons in deciding}

As a person who had a thinking personality, Meta analyzed the pros and cons in making decisions. Ade stated, "She will explain the advantages and disadvantages of running that plan..." (115). This shows that in making decisions, Meta analyzed the pros and cons of a situation. She considered the good and bad sides of a situation related to her decision.

\section{She was objective, making decisions based on logic and facts}

Meta not only analyzed the pros and cons in making a decision, but she was also objective and logical in deciding. She less considered others' feelings. Ade testified, "...She said, you can be sad, but after you finish your job.." (83). There was a situation when Meta knew that her friend had a personal problem. Her friend was sad, but they had a group work assignment that should be finished on time. In order to finish it on time, Meta decided to ask her friend to do her job even though she had a problem that made her sad at that time. This situation suggests that Meta was objective and made decisions based on logic and facts. She less considered others' feelings.

\section{She was consistent and decisive in making and applying decision}

The personality that Meta possessed does not stop with the way she made a decision. She was also consistent in running her decisions/plans. Since Meta gave more attention to the result, she was too forceful in implementing her plan. If she made plans, she would do anything to run her plans. Because of that, others may see her as a decisive person. "...I would be very regretted, and upset.." (100). Ade also stated that " $M^{* * *}$ always insist on doing things that she already planned without considering her condition ..." (105).

Unfortunately, not all people have such a personality. There are some people who like organizing things, and there are also some people who like to be flexible. Because of that, some people may see her as a perfectionist, harsh, or even too bossy, as stated by her, "Because I have a deadline and everything, I have a deadline, some people think that I manage them..." (112). Meta even said, "someone says...l am a kind of person who likes to manage people" (110). This statement was also supported by Ade, who said, "...her plan is good, although we are pushed by it." (16); moreover, Ade also said that, "but sometimes her deadline makes me feel bad because it is very tight...." (12).

In relation to her personality as a thinking person, Meta always worked with plans, and in making plans, she analyzed the pros and cons. In addition, she was also objective and consistent in doing what she had planned even though she had to spend her time and energy. 
People in this personality (Extrovert, Sensing, Thinking and Judging) might look harsh or too bossy, but it is useful to work on their plans (Myers, I. B., McCaulley, M. H., Quenk, N. L., \& Hammer, 1998). Thinking people analyze pros and cons in making a decision; they are objective and logical in their decision making, and they are also consistent and decisive in implementing their decisions (Mudrika, 2011). All of these characteristics were possessed by Meta, and they had made her learn better and successfully.

The theory concerning thinking personality, which makes a good language learner, is very limited, even it is hardly found in the literature, particularly related to the qualities of being able to analyze pros and cons before making decisions and being objective and consistent in applying a decision. The finding in this study, then, proposes that these characteristics might be possessed by a good language learner as it had been proven by Meta as the subject of this study. These characteristics had helped her to shape her learning strategies which resulted in successful language learning.

\section{Judging}

The last type of personality that Meta had was Judging. This type of personality describes how people deal with their outer world. The essential characteristic of judging people is a structured and decided lifestyle. It was found that Meta had some characteristics related to her personality (judging personality). The following are the descriptions of Meta's personality related to judging personality.

\section{She had a structured life, taking control of her life by making many plans.}

The first attribute that Meta had in relation to judging's personality was that she had a structured life. Meta liked making plans, and she planned all her activities, such as things to buy and things to do. Meta believed that planning made her life organized. She said, "Routine makes everything organized... easy to finish" (94). This was also supported by Ade, ".... Her life is planned" (63). She planned her activities not only for today but for the next day. Ade stated, "She always plans ... activities that she will do tomorrow ..." (59).

As a well-organized person, Meta always planned everything, even for a very simple activity. She stated: "Every morning after I wake up, I make a plan about what activities I will do ... (92). Ade also stated that "Everything is planned. She is very detailed." (65). Wilma stated that Meta also plans activity which is related to her language learning in college. Meta's well-organized life was also acknowledged by Wilma, who stated that: "She does planning about some materials that she should study in some days...Example this day she learns about $A$, and the next day she will learn about $B$, etc." (74)

All of the information given by Meta and her classmates confirmed that Meta had a very structured life which was indicated by the fact that she planned everything starting from the biggest to the smallest things, and she paid attention to details. Her organized life was also shown by the evidence that Meta liked to make everything under her control. She felt comfortable when everything was decided and planned. In short, Meta's judging personality had helped her set and achieve her goals in language learning, especially in English, by planning her language learning. 
Setting goals and making plans to achieve her goals showed that Meta was responsible for her own language learning. This means that she had a strong motivation to find her own way to learn English. She also spent her time and her attention learning English outside of the classroom. This also means that she realized that learning English in the classroom was not enough for her to be a good language learner.

\section{Meta was good at meeting deadline}

In order for Meta to achieve her goals in learning, she had a strategy that helped her run her plans, that is, by setting deadlines. She used notes to write her plans, and she also set the time to show when the plans should be executed or accomplished. Meta stated: "...On my to-do list, I also have time that shows when the activity must be done or finished" (139). This statement was also supported by Ade, who said, "She is consistent... on time..." (39). The statements and explanation above show that Meta is good at making and meeting deadlines.

\section{She had difficulties in adapting to unpredictable situations}

Since Meta wanted everything to be perfect and to run well based on her plans, she found it difficult to adapt to unpredictable situations. Meta said: "Actually I don't like...." (131). Ade also said that It was hard for Meta to adapt to unpredictable situations or to anything not in her plans. As stated by Ade: "... She has many plans in order to manage the unpredictable moment" (89). One of the essential characteristics of judging people is a structured life. They feel comfortable when everything is already decided and planned. Therefore, they have difficulties in adapting to unpredictable moments or new environments. Since Meta realized that it was difficult for her to adapt to unpredictable situations, she prepared many plans, and her plans helped her in managing unpredictable situations.

\section{She paid attention to the products}

The next quality that Meta had was productoriented. She paid attention to the results or products. In Meta's view, the most important thing to do was realize her plans because she was a person who paid more attention to results or products than to the process. She confidently stated, "If the result is good, so does the process... (106). The data showed that Meta found the outcome more rewarding than the process of creating something. She made plans and strive so hard to make everything run well as what was had planned and expected.

\section{She organized things and people. (She followed the plans and wants others to follow)}

Because Meta gives more attention to products, she was consistent, responsible, and objective in implementing her plans in order to achieve the goal. She made plans, and she would try hard to make everything run as she planned. Both her friends and Meta realized that Meta liked to manage things and people as stated by her, "Because I have a deadline and everything, I do have a deadline, some people think that I manage them..." (112). She added, "someone says...I ... likes to organize people" (110). Ade also said that in group work, Meta made clear plans, and the members of the group followed them, "We do not act freely, we always follow her plan" (16). All of this evidence indicated that as a judging person, Meta liked to organize things and people. She made plans and took control of everything she had 
planned. Because she worked based on her plans, it was sometimes difficult for her to adapt to an unpredictable situation.

Having discussed all of the qualities that Meta had as a good language learner, it is presumed that a good language learner might have at least four types of personality: extroversion, sensing, thinking, and judging (ESTJ). People who have these types of personalities can quickly make plans and execute them. They also take care of routine details and are good at making and meeting deadlines. Moreover, judging people like to have things are settled and organized, and they pay more attention to the result rather than the process. They also added that one of ESTJ people's weaknesses is their general inability to adapt to new environments or unpredictable moments (The Myers Briggs Foundation, 2017).

The essential characteristics of judging are: they like to have things organized, they make decisions and plans (Myers et al., 1998). In Meta's case, as a judging person, this type of personality played an essential role in her language learning achievement. Since Meta took her own responsibility for her language learning by planning her activities related to language learning and consistent in implementing her plans to achieve the goal in language learning, Meta can be considered as a good language learner. Good language learners find their own way; they take responsibility for their own learning (Zare, 2012). A previous study also found that personality had an effect on the way students learn. The personality created learners' learning strategies and helped them in learning English (Kamarulzaman, 2012).

While Griffiths (2008) states 11 factors that can help a student become a good language learner, this study only discusses one of them, which was personality. It is expected that future researchers will discuss more factors, which include culture, metacognition, personality, motivation, age, autonomy, gender, learning style, belief, aptitude, and learning strategy. Moreover, it will be better if the researchers cover all of the 11 factors proposed by Griffiths (2008).

\section{Conclusion}

As a good language learner, the subject of this research, Meta, had four types of personality, namely, extroversion, sensing, thinking, and judging. In terms of the extrovert, she possessed specific characteristics such as talkativeness, confidence, enthusiasm, assertiveness, and getting active involvement. As a sensing person, she remembered and paid attention to the details of information; and she learned best by doing or experimenting. As a sensing person, she analyzed the pro and cons in making decisions; she was objective, and she made decisions based on logic and facts, and she is consistent and decisive in making and applying decisions. Moreover, she may be looked bossy. In terms of judging as her last personality, she had a structured life, taking control of her life by making many plans; she was good at meeting deadlines, but she had difficulty in adapting to unpredictable situations. Moreover, she gave more attention to the product rather than the process.

\section{References}

Alan E. Kazdin. (2000). Encyclopedia of Psychology. American psychological association. 
Creswell, J. W. (2014). Research Design Qualitative, Quantitative and Mixed Methods Approaches (4th ed.). Sage.

Denzin, N. K. (2006). Sociological Methods A Sourcebook. Routledge.

Dörnyei, Z., \& Ushioda, E. (2009). Motivation, Language Identity and the L2 Self. Multilingual Matters.

Griffiths, C. (2008). Lessons from Good Language Learners. In Cambridge University Press. Cambridge University Press. https://doi.org/10.1017/cbo978051149766 7.022

Huberman, A. M., \& Miles, M. B. (2002). The Qualitative Researcher's Companion. Sage Publication.

Jafari, S., Jafari, S., \& Kafipour, R. (2020). How Does She Learn English? A Case of a Successful Blind Language Learner. Vision: Journal for Language and Foreign Language Learning, 9(2),

131. https://doi.org/10.21580/vjv10i16727

Kamarulzaman, W. (2012). Critical Review on Affect of Personality on Learning Styles. Online Submission, March, 1-7.

Lightbown, P. M. and N. S. (2013). How Languages are Learned (4th ed.). Oxfor University Press.

Lisa A. Guion, David C. Diehl, and D. M. (2011). Triangulation: Establishing the Validity of Qualitative Studies. In University of Florida (pp. 1-3). https://doi.org/10.32473/edisfy394-2002

Mammadov, S. (2016). Personality Predictors Of Academic Achievement In Gifted Students : Mediation By Socio-Cognitive And Motivational Variables. In wiliam and Mary. wiliam and Mary.
Marshall, C., \& Rossman Permalink, G. B. (1990). Designing Qualitative Research. Issues in Applied Linguistics, 1(2), 1(2). http://escholarship.org/content/qt3m25g8j 8/qt3m25g8j8.pdf

Mudrika, N. (2011). Mbti. In wordpress. https://doi.org/10.1007/978-0-387-799483_5359

Myers, I. B., McCaulley, M. H., Quenk, N. L., \& Hammer, A. L. (1998). MBTI manual: $A$ guide to the development and use of the Myers-Briggs Type Indicator. Consulting Psychologists Press.

Orb, A., Eisenhauer, L., \& Wynaden, D. (2001). Ethics in qualitative research. Journal of Nursing Scholarship, 33(1), 93-96. https://doi.org/10.1111/j.15475069.2001.00093.x

Pittenger, D. J. (2005). Cautionary comments regarding the Myers-Briggs type indicator. Consulting Psychology Journal, 57(3), 210221. https://doi.org/10.1037/10659293.57.3.210

Robert K Yin. (2000). Case Study Research Design and Methods Third Edition. In Sage Publication (3rd ed., Vol. 3, Issue 3). https://doi.org/10.1300/J145v03n03_07

Takeuchi, O. (2003). What can we learn from good foreign language learners? A qualitative study in the Japanese foreign language context. System, 31(3), 385-392. https://doi.org/10.1016/S0346251X(03)00049-6

The Myers Briggs Foundation. (2017). MyersBriggs Type. 37.

Woosley, E. R. (2001). a Look At the Relationships Between MBTI and MODE [WisconsinStout]. 
Puji Astuti Amalia, Aridah

https://minds.wisconsin.edu/handle/1793/ 40261

Zare, P. (2012). Language learning strategies among EFL/ESL learners a review of literature. International Journal of Humanities and Social Science, 2(5), 162169. 